\title{
The CM-Proteins from Cereal Endosperm:
}

\section{Immunochemical Relationships}

\author{
J. PAZ-ARES, C. HERNANDEZ-LUCAS, G. SALCEDO, \\ C. ARAGONCILLO, F. PONZ AND F. GARCIA-OLMEDO
}

Departamento de Bioquímica, E. T. S. Ingenieros Agrónomos-UPM, Madrid-3, Spain

Received 4 August 1982

\begin{abstract}
A BSTRACT
The CM-proteins, which are salt-soluble proteins that can be extracted with chloroform:methanol $(2: 1, v / v)$, seem to be present in the endosperm of all the cereal species investigated. Antibodies raised against a mixture of the barley $\mathrm{CM}$-proteins $(\mathrm{A}-\mathrm{H})$ cross-reacted with wheat and rye proteins in Ouchterlony tests and a detailed study was carried out for purified wheat (CM1, CM2, CM3, CM3') and barley (CMa, CMb, CMc, CMd) CM-proteins.

${ }^{35} \mathrm{~S} \mid$-Cysteine-labelled endosperm proteins from wheat and barley were investigated by immunoprecipitation, electrophoresis and fluorography using the antibodies $(\mathrm{A}-\mathrm{H})$ and also those to a mixture of wheat $\mathrm{CM}$-proteins and to $\mathrm{CMd}$. There was complete antigenic identity for all the wheat proteins and $\mathrm{CMd}$, some of the other proteins showed partial antigenic identity.

Previously proposed genetic and biochemical relationships among these proteins were confirmed in the present study.
\end{abstract}

Key words: CM-Protein; Cereal endosperm; Immunochemistry.

\section{INTRODUCTION}

It is becoming increasingly evident that there is considerable homology among endosperm proteins from wheat, barley and rye. Miflin, Field, and Shewry (1982) have reviewed the evidence for three homologous groups, designated S-poor, S-rich, and high-molecular-weight prolamins, respectively. Homology has also been demonstrated for the thionins (GarciaOlmedo, Carbonero, and Jones, 1982) and for two groups of hydrophobic proteins with molecular weights under 25000 , designated low-molecular-weight prolamins and CMproteins, respectively (Rodríguez-Loperena, Aragoncillo, Torres, Carbonero, and GarciaOlmedo, 1975b; Salcedo, Sánchez-Monge, and Aragoncillo, 1982a; Prada, Sánchez-Monge, Salcedo, and Aragoncillo, 1982; Salcedo, Sánchez-Monge, Argamentería and Aragoncillo, $1982 b$ ). In barley, these two groups are included in the previously designated A-hordeins. Individual CM-proteins from barley and wheat have been purified and different intra- and interspecific relationships have been proposed among them on the basis of biochemical and genetic studies (Aragoncillo, Rodriguez-Loperena, Carbonero, and Garcia-Olmedo, 1975; Salcedo, Aragoncillo, Rodríguez-Loperena, Carbonero, and García-Olmedo, 1978a; Salcedo, Rodriguez-Loperena and Aragoncillo, 1978b; Salcedo et al., 1982a). The aim of the present study is to further characterize the CM-proteins as a group of homologous proteins and to confirm the previously proposed relationships using immunochemical techniques. 


\section{MATERIALS AND METHODS}

\section{Proteins}

Chloroform:methanol $(2: 1, \mathrm{v} / \mathrm{v})$ extracts were prepared from mature, delipidated endosperms of Hordeum vulgare cv. Zephyr. Triticum aesticum cv. Candeal (hexaploid), T. turgidum cvs. Senatore Capelli and Ledesma (tetraploid), Zea mal's LP-2162. Secale cereale INIA-C/171M, Avena sativa cv. Cartuja, and Oryza sativa commercial brand SOS, following published procedures (RodriguezLoperena, Aragoncillo. Carbonero, and Garcia-Olmedo 1975a). A mixture of proteins CMa. CMb, $\mathrm{CMc}$ and $\mathrm{CMd}$ from barley and pure CMd were obtained as described (Aragoncillo, Sanchez-Monge, and Salcedo 1981: Salcedo et al., 1982a). A mixture of proteins CM1, CM2, and CM3 from wheat was obtained from the CM extract of $T$. aesticum by Sephadex G-100 filtration and further fractionation of the peak under $25000 \mathrm{~mol}$. wt. by preparative disk electrophoresis carried out in $7.5 \%$ polyacrylamide gels $(7.5 \mathrm{~mm} \times 150 \mathrm{~mm})$. using aluminium lactate buffer, $\mathrm{pH} 3.2,3.0 \mathrm{M}$ urea, $10 \mathrm{~V} \mathrm{~cm}^{-1}, 3 \mathrm{~h}$ at room temperature. The proteins were made visible by treating the gel with a $60 \%$ saturated $\left(\mathrm{NH}_{4}\right)_{2} \mathrm{SO}_{4}$ solution. The appropriate part of the gel was homogenized in 2 vols of $0.01 \mathrm{M}$ phosphate buffer-saline $(\mathrm{pH} 6.5), 3.0 \mathrm{M}$ urea, and used as such in the immunization experiments. Small amounts of purified proteins CM2 and CM3 from $T$. aesticum. CM2, CM3, and $\mathrm{CM} 3^{\prime}$ from $T$. turgidum, CMa. CMb, $\mathrm{CMc}$ and $\mathrm{CMd}$ from $H$. vulgare. which were used in immunodiffusion tests and as electrophoretic markers were available from prcvious studies (Salcedo et al., 1978b: Salcedo et al.. 1982a).

Proteins synthesized by developing endosperm of $T$. aestivum $\mathrm{cv}$. Candeal and $H$. vulgare $\mathrm{cv}$. Bomi were labelled with ${ }^{35} \mathrm{~S} \mid$-cysteine $\left(933 \mathrm{Ci} \mathrm{mmol}^{-1}\right.$. NEN) essentially as described by Donovan and Lee (1977): ears of both species were cut $18 \mathrm{~d}$ after anthesis, leaving $5-10 \mathrm{~cm}$ of stem. and each of them was placed in a conical tube with $0.5 \mathrm{ml}$ of a sulphur-free nutrient solution containing $100-300 \mu \mathrm{Ci}$ of labelled precursor. Two successive $0.5 \mathrm{ml}$ aliquots of the same nutrient solution without label were added in the same tube and the ear was then transferred to a refrigerated $\left(4^{\circ} \mathrm{C}\right) 25 \mathrm{ml}$ erlenmeyer flask with nutrient solution for $48 \mathrm{~h}$. After this period $80 \%$ of the radioactivity was recovered as trichloroacetic acid insolublc $\mathrm{ct} \mathrm{min}^{-1}$. The ears were freeze-dried and the endosperm obtained by hand disscction.

\section{Preparation of antibodies}

Antibodies were raised against a mixture of barley $\mathrm{CM}$-proteins $(\mathrm{A}-\mathrm{H})$, a mixture of wheat CM-proteins (A-T) and highly purified CMd from barley $(\mathrm{A}-\mathrm{Hd})$ in adult female rabbits following consecutive subcutaneous and intraperitoneal injections of the antigens at 3-4 week intervals. In the cases of $\mathrm{A}-\mathrm{H}$ and $\mathrm{A}-\mathrm{Hd}$, the proteins were coupled to bovine serum albumin and injected together with Freund's complete adjuvant (Difco) according to Tai and Chcy (1978). Starting protein doses were $2.0 \mathrm{mg}$ /injection for the barley CM-protein mixture and $1.0 \mathrm{mg} /$ injection for CMd. In the case of wheat $\mathrm{CM}$-proteins, the above described mixture of proteins and polyacrylamide gel was injected (initial dose $-4.0 \mathrm{mg}$ of protein per injcction). Blood was withdrawn when useful antibody titres were obtained and sera were prcpared and stored at $-20^{\circ} \mathrm{C}$. Antibodies were purified by precipitation with $40 \%$ saturated $\left(\mathrm{NH}_{4}\right)_{2} \mathrm{SO}_{4}$ and by passage through a barley-CMd-Sepharose affinity column prepared according to Shapiro. Taylor, McKnight, Palacios, Gonzalez, Kiely, and Schimke (1974).

\section{Immunodiffusion and immunoprecipitation}

Ouchterlony plates prepared according to Garvey, Cremer, and Sussdorf (1977) were used to test for immunological cross-reactivity. Borate buffer-saline $\mathrm{pH} 8.3$ (BBS; $1.25 \mathrm{mM}$ sodium tetraborate, $5.0 \mathrm{mM}$ boric acid, $0.15 \mathrm{M} \mathrm{NaCl}$ ) was used both for the plates and to dissolve the proteins to be applied. Purified $\mathrm{CM}$-proteins and $0.5 \mathrm{M} \mathrm{NaCl}$ endosperm extracts were used. The latter were obtained by extracting twice with 8 vols of $0.5 \mathrm{M} \mathrm{NaCl}$ and the pooled extracts were precipitated with $12.5 \%$ trichloroacetic acid and centrifuged for $20 \mathrm{~min}$ at $6000 \times \mathrm{g}$. The precipitates were washed with acetone, air dried. and redissolved in BBS $\left(5.0 \mu \mathrm{mg} \mathrm{m}^{-1}\right.$ of original ground endosperm). Fifteen microlitres of this solution, or $8-10 \mu \mathrm{g}$ of purified proteins in $15 \mu \mathrm{l}$ of BBS, were applied per well. The purified proteins were readily soluble in BBS, but some insoluble material remained after sonication in the case of the trichloroacetic acid precipitates.

Immunoprecipitation was carried out essentially as in Shapiro and Young (1981): the labelled protein extract $(0.5 \mathrm{M} \mathrm{NaCl}, 30 \mu \mathrm{l})$ was made up to a $200 \mu \mathrm{lBBS}(\mathrm{pH} 8.3)$ solution, to which $10 \mu \mathrm{l}$ of the appropriate $\operatorname{lgG}$ preparation was added and the mixture incubated at $37^{\circ} \mathrm{C}$ for $1 \mathrm{~h}$ and then at $4^{\circ} \mathrm{C}$ for $2-\mathrm{I} 4 \mathrm{~h}$. Finally. $80 \mu \mathrm{l}$ of IgG Sorb (The Enzyme Center. Inc.) were added and aftcr a $30 \mathrm{~min}$ incubation at $4{ }^{\circ} \mathrm{C}$ the precipitate was centrifuged $(10000 \times g)$ through a cushion of $1.0 \mathrm{M}$ sucrose, $1 \%$ Triton X-100 and I\% Na-deoxycholate in BBS. The precipitates were repeatedly washed in BBS, $1 \%$ Triton X-100, $1 \%$ Na-deoxycholate, before electrophoresis. 


\section{Electrophoresis and fluorography}

Starch gel electrophoresis (SGE) of chloroform:methanol extracts was carried out in $0.1 \mathrm{M}$ aluminium lactate buffer, $\mathrm{pH} 3 \cdot 2,3 \cdot 0 \mathrm{M}$ urea, for $4.5 \mathrm{~h}$ at $20 \mathrm{~V} \mathrm{~cm}^{-1}$ and $5{ }^{\circ} \mathrm{C}$. Gels were stained with $0.05 \%$ nigrosine in methanol-water-acetic acid $(5: 5: 1$, by vol) for $16 \mathrm{~h}$. Polyacrylamide (10\%) gel electrophoresis (PAGE) was carried out with the same buffer system, when fluorography was to be performed. Sodium dodecyl sulphate-polyacrylamide gel electrophoresis (SDS-PAGE) was carried out according to Laemmli (1970) and gels were stained with Coomassie Brilliant Blue G-250 (Blakesley and Boezi, 1977). Fluorography was performed as described by Laskey and Mills (1975).

\section{RESULTS}

The CM-proteins are salt-soluble proteins which can be extracted with chloroform : methanol $(2: 1, v / v)$. Electrophoretic patterns of the CM fractions from barley, tetraploid and hexaploid wheat, rye, oats, and maize are presented in Fig. 1. The main components from barley and wheat have been previously purified and partially characterized (García-Olmedo and Carbonero, 1970; Redman and Ewart, 1973; Salcedo et al., 1978b; Salcedo et al., 1982a), whereas those from the other species have not yet been investigated in detail.

Antibodies raised against a mixture of barley CM-proteins $(\mathrm{A}-\mathrm{H})$ were used to carry out double-diffusion Ouchterlony tests with different extracts and purified proteins. Salt extracts from the endosperms of wheat, barley, rye, rice, oats and maize, as well as the purified $\mathrm{CM}$-fractions from wheat and barley, were tested against $\mathrm{A}-\mathrm{H}$ as shown in Fig. 2. Two precipitin lines common to both CM fractions and to the salt extracts of wheat, barley and rye were observed, although the relative positions of the lines were different for the purified fractions than for the crude extracts, probably due to differences in the relative concentrations of the antigens in the two types of preparations. No precipitin lines were detected in the cases of oats, maize and rice.

Available purified CM components from wheat and barley were also tested against $\mathrm{A}-\mathrm{H}$ (Fig. 3). A single precipitin line was obtained for CMd from barley, CM2 and CM3 from hexaploid wheat, and CM3 and CM3' from tetraploid wheat, with no spurs at the junctions, indicating complete antigenic identity for all these proteins. Proteins $\mathrm{CMa}$ and $\mathrm{CMb}$ from barley yielded a weak common precipitin line which seemed to be partially identical with that

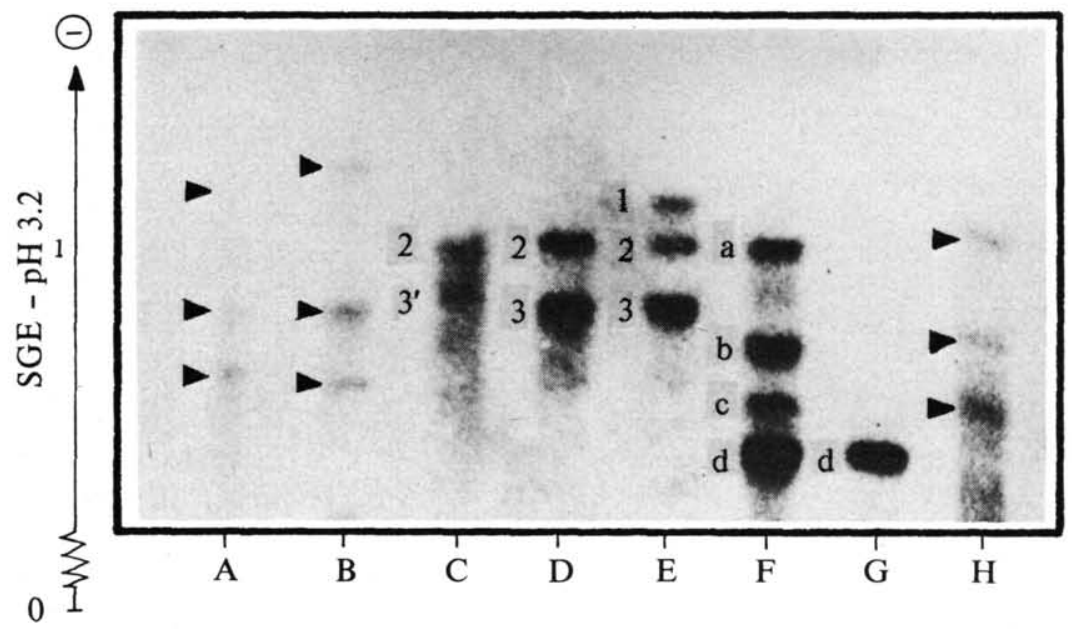

FIG. 1. CM-proteins from different species fractionated by starch-gel electrophoresis at pH 3.2. (A) Avena sativa; (в) Secale cereale; (C) Triticum turgidum cv. Ledesma; (D) T. turgidum cv. S. Capelli; (E) T. aestivum; (F) Hordeum vulgare; (G) Purified CMd; (H) Zea mays. Proteins indicated with numbers or letters have been purified and characterized, whereas proteins indicated with arrows have not yet been isolated. 


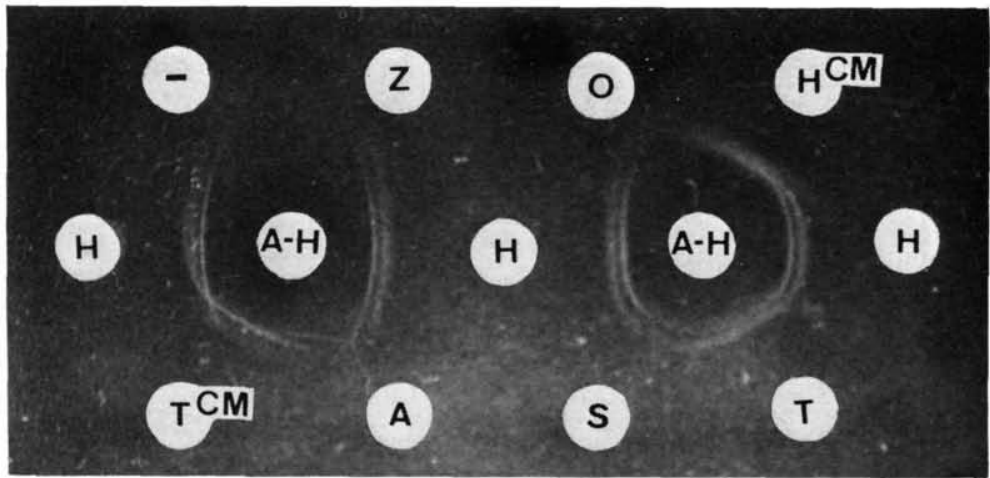

FIG. 2. Double-diffusion Ouchterlony tests of salt extracts of hexaploid wheat (T), barley (H), rye (S), rice $(\mathrm{O})$, eats $(\mathrm{A})$, maize $(\mathrm{Z})$, mixture of wheat $\mathrm{CM}$-proteins $\left(\mathrm{T}^{\mathrm{CM}}\right)$, mixture of barley $\mathrm{CM}$-proteins

$\left(\mathrm{H}^{\mathrm{CM}}\right)$, and buffer $(-)$, against antibodies raised for a mixture of barley $\mathrm{CM}$-proteins $(\mathrm{A}-\mathrm{H})$.
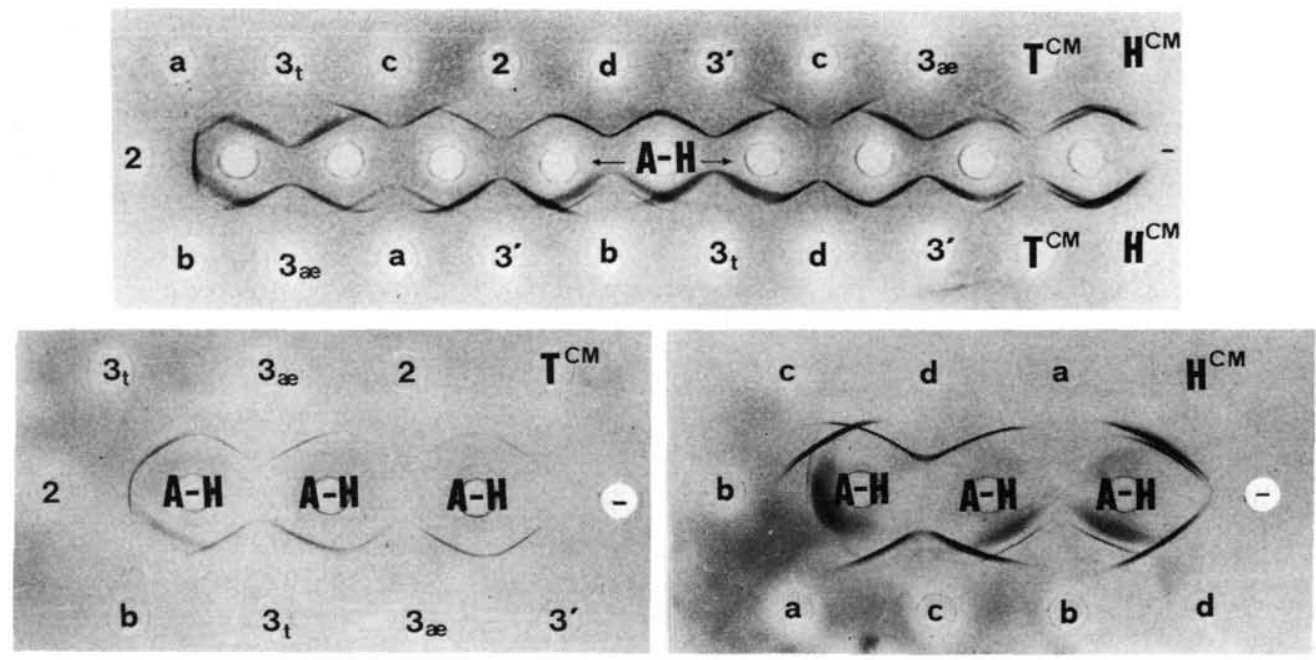

FIG. 3. Ouchterlony test of the following purified proteins: CM2 and CM3 from T. aestivum (2, $\left.3_{\mathrm{ae}}\right)$; CM3 and CM3' from T. turgidum cultivars S. Capelli and Ledesma, respectively $\left(3_{t}, 3^{\prime}\right){ }^{\prime} \mathrm{CMa}, \mathrm{CM} b$, CMc and CMd from H. vulgare (a, b, c, d). Other symbols as in Fig. 2.

of CM3 from wheat and CMd from barley; whereas CMc gave a sharp precipitin line which appeared as different from that of CMd, but partially identical with CM3.

A more detailed study of immunochemical relationships was carried out for the wheat and barley components using $\mathrm{A}-\mathrm{H}$ and the antibodies raised against highly purified $\mathrm{CMd}$ from barley $(\mathrm{A}-\mathrm{Hd})$ and against a mixture of $\mathrm{CM}$-proteins from wheat $(\mathrm{A}-\mathrm{T})$ to precipitate $\left[{ }^{35} \mathrm{~S}\right]$-labelled proteins from developing endosperms of the two species. The immunoselected proteins were analysed by two electrophoretic methods, pH 3.2-PAGE and SDS-PAGE, and detected by fluorography. The three antibody preparations (A-H, A-Hd and A-T) selected CM1, CM2 and CM3 from wheat (Fig. 4). A fourth, not characterized component from developing wheat endosperm was also recognized (Fig. 4B). Results obtained for developing barley endosperm are presented in Fig. 5. The A-H preparation selected CMa, $\mathrm{CMb}, \mathrm{CMc}$ and $\mathrm{CMd}$, whereas $\mathrm{A}-\mathrm{T}$ and $\mathrm{A}-\mathrm{Hd}$ only precipitated $\mathrm{CMd}$ following our normal procedure. However, when excess of either antibody was used, $\mathrm{CMa}, \mathrm{CMb}$ and $\mathrm{CMc}$ could also be precipitated (not shown). 

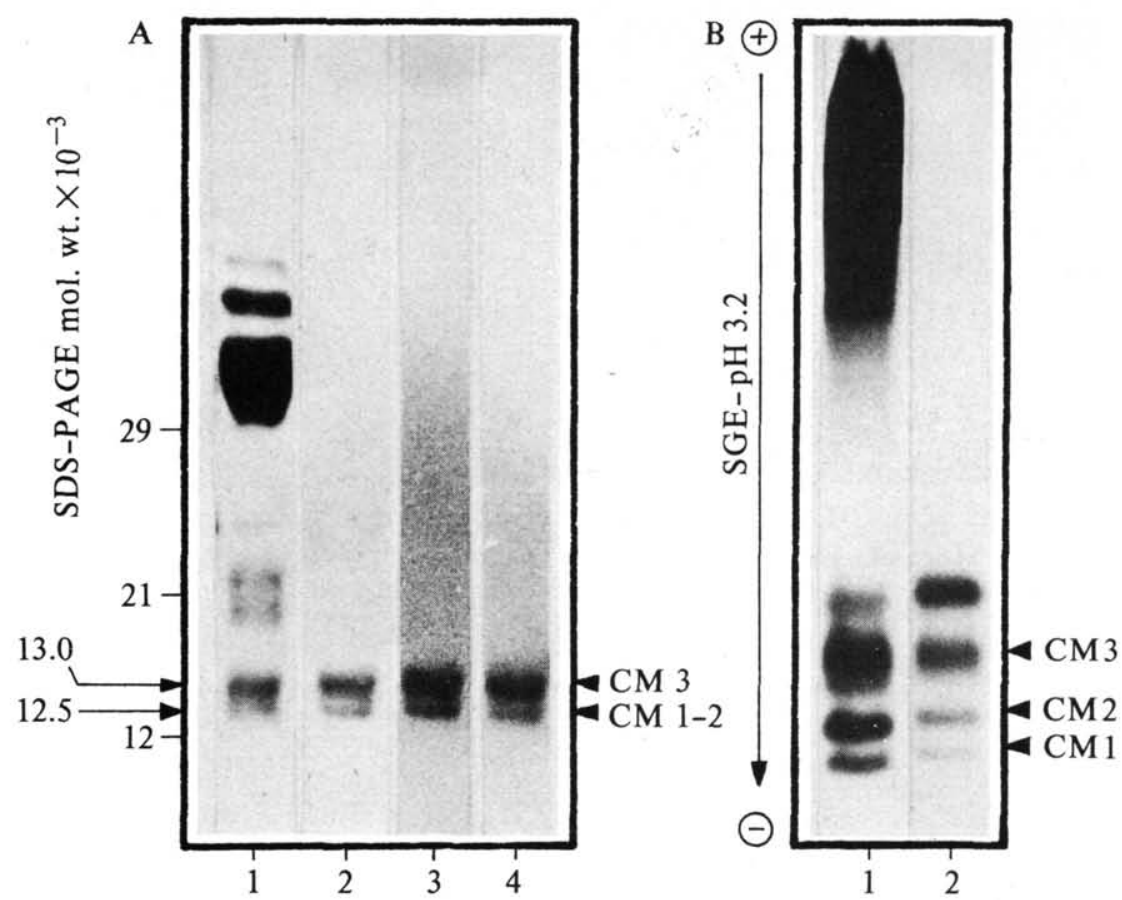

FIG. 4. Electrophoresis and fluorography of $\left[{ }^{35} \mathrm{~S}\right]$-labelled proteins from $0.5 \mathrm{M} \mathrm{NaCl}$ extract of $T$. aestivum endosperm selected by immunoprecipitation with different antibody preparations. (A) SDS-PAGE (12.5\%): (1) chloroform : methanol (2:1, v/v) extract; (2) A-T; (3) A-H; (4) A-Hd. (B) pH 3.2-PAGE (10\%): (1) chloroform:methanol (2:1, v/v) extract; (2) A-H. Purified proteins from mature wheat endosperm were also inserted in the gels and their positions marked with radioactive ink. Mol. wt. standards used were carbonic anhydrase (29 K), soybean trypsin inhibitor (21 K), and cytochrome c $(12 \mathrm{~K})$, from Serva AG, and their positions were equally marked.

\section{DISCUSSION}

Proteins with the general properties of CM-proteins have been found not only in the species represented in Fig. 1, but in all cereal endosperms investigated, including wild Gramineae such as Aegilops (Delibes and Garcia-Olmedo, 1973) and Agropyron (Rodriguez-Loperena et al., 1975b). The negative Ouchterlony tests against A-H of some of these species could be due to a lack of common antigenic determinants with barley, a lower proportion of CM-proteins in the endosperms of these species, or to a lower solubility in the buffer used in the test.

Immunochemical relationships among CM-proteins from wheat and barley are summarized in Table 1, which also includes compositional index values for all possible binary comparisons. For convenience to the reader, the index used is $S \Delta N r=S \Delta N / 0.42 N$, where $S \Delta N$ is the compositional index proposed by Cornish-Bowden (1980) and $N$ is the number of amino acid residues of the smaller protein of the two being compared. Pairs of proteins with $S \Delta N<0.42 N$ (equivalent to $S \Delta N r<1$ ) have a $95 \%$ probability of having sequence homology and if $0.42 N<S \Delta N<0.93 N$ (in the new terms $1<S \Delta N r<2.2$ ) the proteins have sequence homology in about $90 \%$ of the cases (Cornish-Bowden, 1980). Out of several thousand comparisons in which $S \Delta N r<1$, Cornish-Bowden (1981) found only one pair of proteins which did not have sequence homology, while in comparisons for which $S \Delta N r>2 \cdot 2$ practically always significant sequence homology was lacking. In the present case, for all 36 binary comparisons $S \Delta N r<2 \cdot 2$, and for 21 of them $S \Delta N r<1$, which indicates a close web 

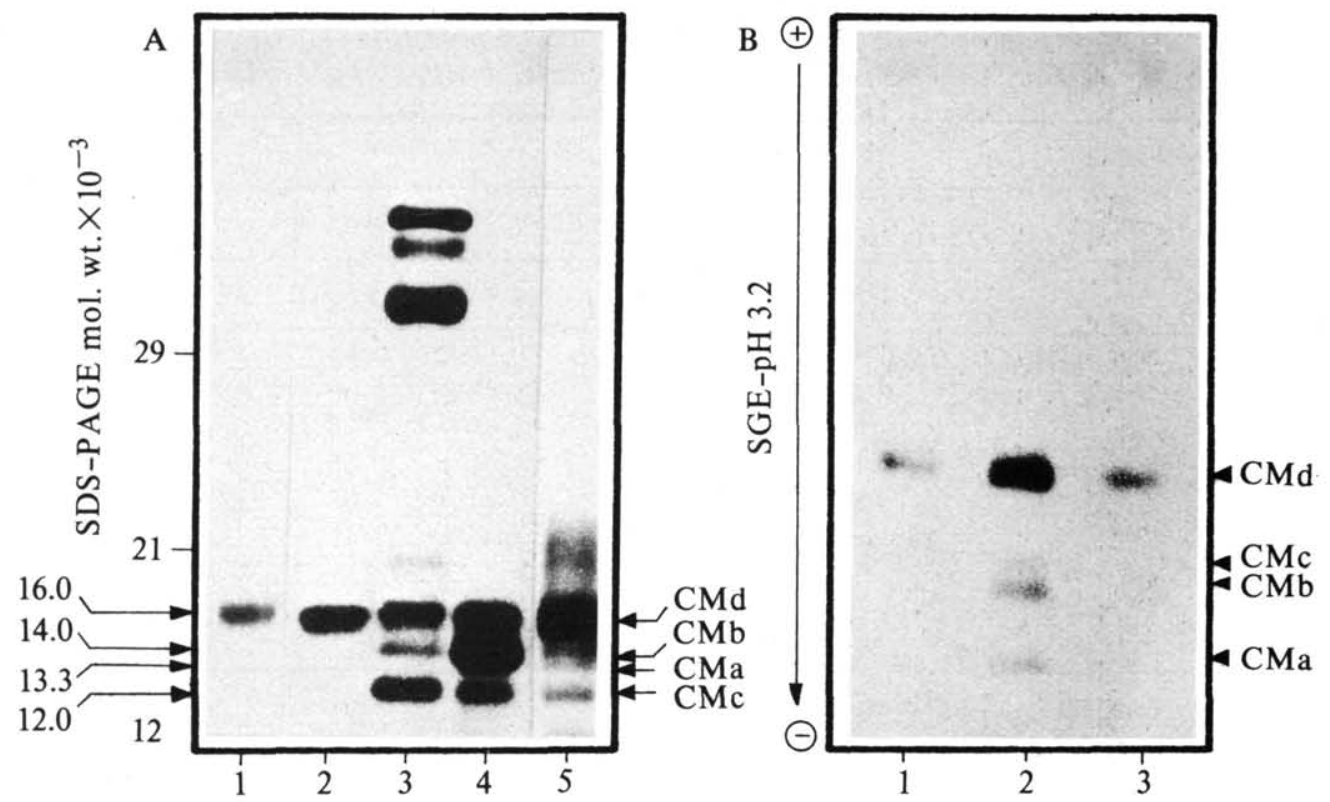

FIG. 5. Electrophoresis and fluorography of $\left|{ }^{35} \mathrm{~S}\right|$-labelled proteins from $0.5 \mathrm{M} \mathrm{NaCl}$ extract of $H$. vulgare selected by immunoprecipitation with different antibody preparations. (A) SDS-PAGE (12.5\%): (1) A-T; (2) A-Hd; (3) chloroform:methanol (2:1, v/v) extract; (4) A-H; (5) lane 2, fluorography overexposed. (в) $\mathrm{pH} 3 \cdot 2-\mathrm{PAGE}$ (10\%): (1) A-T; (2) A-H; (3) A-Hd. Purified proteins from mature barley endosperm were also inserted in the gels and their positions marked with radioactive ink. Mol. wt. standards were as in Fig. 4.

of sequence homology relationships. The immunochemical results reported here fully support this idea.

Structural genes for proteins CM1, CM2 and CM3 have been assigned to chromosomes 7D, 7B and 4A, respectively (Garcia-Olmedo and Carbonero, 1970; Aragoncillo et al., 1975). Proteins CM1 and CM2 were considered as derived from the same ancestral protein (homoeologues) on the basis of their amino acid compositions $(S \Delta N r<1)$ and of the homoeologous chromosomal locations of their structural genes (García-Olmedo and Carbonero, 1970; Aragoncillo et al., 1975), but, in the case of CM3, homoeology, although suspected, could not be fully demonstrated. The present immunochemical evidence supports the hypothesis that the three proteins are homoeologous and suggests that a $7 \mathrm{~A} / 4 \mathrm{~A}$ chromosomal translocation might have taken place in the A genome, similar to the $7 \mathrm{~B} / 4 \mathrm{~B}$ translocation postulated for the B genome (Kobrehel and Feillet, 1975; Benito and Pérez de la Vega, 1979; Prada et al., 1982).

Proteins CM3, present in most cultivars of T. turgidum, and CM3', present in only a few cultivars, were found to be very similar $(S \Delta N r=0.26)$ and to segregate as allelic variants in appropriate crosses (Salcedo et al., 1978a). The differences found between CM3 from $T$. aestivum and CM3 from $T$. turgidum $(S \Delta N r=0 \cdot 19)$ were those expected between two preparations of the same protein from the same source (unpublished). Accordingly, CM3 from the two sources and CM3' show strong immunological cross-reactions.

Proteins CM3 from wheat and CMd from barley are closely related, as judged by their amino acid compositions and by their unique solubility in chloroform : methanol $(7: 1, \mathrm{v} / \mathrm{v})$. This fully confirmed by the data reported here.

Both the biochemical and immunological evidence (Table 1) support the inclusion of proteins $\mathrm{CMa}, \mathrm{CMb}$ and $\mathrm{CMc}$ in the same homology group with the rest of the $\mathrm{CM}$-proteins 
T A B LE 1. Summary of immunochemical relationships ${ }^{a}$ and relative compositional difference indexes $^{b}$ for binary comparisons between $C M$-proteins from wheal and barley

\begin{tabular}{|c|c|c|c|c|c|c|c|c|c|}
\hline & \multicolumn{9}{|c|}{ CM-Proteins } \\
\hline & \multicolumn{4}{|c|}{ H. vulgare } & \multicolumn{3}{|c|}{ T. aestivum } & \multicolumn{2}{|c|}{ T. turgidum } \\
\hline & a & $b$ & $\mathrm{c}$ & $\mathrm{d}$ & 1 & 2 & 3 & $3 \mathrm{t}$ & $3^{\prime}$ \\
\hline a &. & $1 \cdot 10$ & 0.98 & 1.46 & 0.54 & 0.50 & 0.82 & 1.09 & 0.67 \\
\hline b & w & 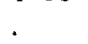 & 1.24 & 0.96 & 1.49 & $1 \cdot 36$ & 1.00 & 0.79 & 0.75 \\
\hline c & & & . & 1.62 & 1.59 & 1.68 & 0.92 & 0.97 & 0.56 \\
\hline d & W & w & W & & 1.72 & 1.65 & 0.56 & 0.49 & 0.92 \\
\hline 1 & & & & $S$ & . & 0.21 & 1.04 & 1.51 & 0.82 \\
\hline 2 & & & & $\mathrm{~S}$ & $S$ & & $1 \cdot 18$ & 1.54 & 0.90 \\
\hline 3 & w & w & w & $\mathrm{S}$ & $S$ & $S$ & & 0.19 & 0.48 \\
\hline $3 t$ & & & & $\mathbf{S}$ & & S & $S$ & . & 0.26 \\
\hline $3^{\prime}$ & & & & $\mathbf{S}$ & & $S$ & $S$ & $S$ & \\
\hline
\end{tabular}

${ }^{a} \mathrm{~S}$, strong cross-reactivity; $\mathrm{W}$, weak cross-reactivity.

${ }^{b}$ Relative compositional difference index: $S \Delta N r=S \Delta N / 0.42 N$; based on Cornish-Bowden (1980); $S \Delta N r<1,95 \%$ confidence of homology; $1<S \Delta N r<2 \cdot 2$, homology is probable; $S \Delta N r>2 \cdot 2$, homology is improbable.

included in this study. This would imply the existence of repeated loci (4) for these proteins in diploid barley, whereas in hexaploid wheat, one locus per diploid genome seems to exist.

The present report demonstrates close relationships among CM-proteins of wheat, barley and rye. Further work will be required to characterize $\mathrm{CM}$-proteins from other Gramineae and to establish their structural relationships.

\section{ACKNOWLEDGEMENTS}

We thank J. Garcia Guijarro for his technical assistance. This work was supported by a grant from the Fundación Ramón Areces.

\section{LITERATURE CITED}

Aragoncillo, C., Rodriguez-Loperena, M. A., Carbonero, P., and Garcia-Olmedo, F., 1975. Chromosomal control of non-gliadin proteins from the $70 \%$ ethanol extract of wheat endosperm. Theoretical and Applied Genetics, 45, 322-6.

- Sanchez-Monge, R., and Salcedo, G., 1981. Two groups of low molecular weight hydrophobic proteins from barley endosperm. Journal of Experimental Botany. 32, 1279-86.

Benito, C., and Perez de la Vega, M., 1979. The chromosomal location of peroxidase isozyme of the wheat kernel. Theoretical and Applied Genetics, 55, 73-6.

Blakesley, R. W., and BoEZI, J. A., 1977. A new staining technique for proteins in polyacrylamide gels using Coomassie Brilliant Blue G250. Analytical Biochemistry, 82, 580-2.

CoRnish-Bowden, A., 1980. Critical values for testing the significance of amino acid composition indexes. Ibid. 105, $233-8$.

1981. Interpretation of amino acid compositions. TIBS, 6, 217-9.

Delibes, A., and Garcia-Olmedo, F., 1973. Biochemical evidence of gene transfer from the $\mathrm{M}^{\mathrm{v}}$ genome of Aegilops ventricosa to hexaploid wheat. Proceedings of the 4th International Wheat Genetics Symposium, Columbia MO, Pp. 161-6.

Donovan, G. R., and LEe, J. W., 1977. The growth of detached wheat heads in liquid culture. Plant Science Letters, 9, 107-13.

Garcia-Olmedo, F., and Carbonero, P., 1970. Homeologous protein synthesis controlled by homoeologous chromosomes in wheat. Phytochemistry, 9, 1495-7.

- and JonEs, B. L., 1982. Chromosomal location of genes that control wheat endosperm proteins. Advances in Cereal Science Technology, 5, 1-47. 
Garvey, J. S.. Cremer. N. E., and Sussdorf, D. H., 1977. Gel diffusion. In Methods in immunology. W. A. Benjamin. Inc.. Reading. Pp. 313-27.

Kobrenel, H., and Feillet, P., 1975. Identification of genomes and chromosomes involved in peroxidase synthesis of wheat seed. Canadian Journal of Botany, 53, 2336-44.

LaEmml. U. K.. 1970. Cleavage of structural proteins during the assembly of the head of bacteriophage T4. Nature, 227, 680-5.

Laskey. R. A.. and Mills. A. D., 1978. Quantitative film detection of ${ }^{3} \mathrm{H}$ and ${ }^{14} \mathrm{C}$ in polyacrylamide gels by fluorography. European Journal of Biochemistry, 56, 335-41.

Miflin. B. J.. Field, J. M.. and Shewry, P. R., 1982. Cereal storage proteins and their effect on technological properties. In Seed proteins. Eds J. Mossé and J. Daussant. Academic Press, London (in press).

Prada. J.. Sanchez-Monge. R.. Salcedo, G., and Aragoncillo, C., 1982. Isolation of the major low molecular weight gliadins from wheat. Plant Science Letters, 25, 281-9.

Redman. D. G.. and Ewart, J. A. D., 1973. Characterization of three proteins found in chloroform-methanol extracts of flour. Journal of the Science of Food and Agriculture, 24, $629-36$.

Rodriguez-loperena, M. A.. Aragoncillo, C., Carbonero, P., and Garcia-Olmedo, F., $1975 a$. Heterogeneity of wheat endosperm proteolipids (CM-proteins). Phytochemistry, 14, 1219-23.

— Torres, J. V.. Carbonero, P., and Garcia-Olmedo, F., 1975b. Biochemical evidence of chromosome homeology among plant genera. Plant Science Letters, 5, 387-93.

Salcedo, G.. Aragoncillo, C., Rodriguez-loperena, M. A., Carbonero, P., and GarciaOlmedo, F.. 1978a. Differential allelic expression at a locus encoding an endosperm protein in tetraploid wheat (Triticum turgidum). Genetics, 89, 147-56.

- Rodriguez-Loperena, M. A.. and Aragoncillo, C., 1978b. Relationships among low MW hydrophobic proteins from wheat endosperm. Phytochemistry, 17, 1491-4.

- Sánchez-Monge. R., and Aragoncillo, C., 1982a. The isolation and characterization of low molecular weight hydrophobic salt soluble proteins from barley. Journal of Experimental Botany, 33, 1325-31.

- Argamenteria, A., and Aragoncillo, C., 1982 $b$. Low molecular weight prolamins: purification of a component from barley endosperm. Journal of Agricultural and Food Chemistr., 30, $1155-7$.

Shapiro, D. J., Taylor, J. M., McK night, G. S., Palacios, R., Gonzalez, C., Kiely, M. L., and Schimke, R. T.. 1974. Isolation of the oviduct ovalbumin and rat liver albumin polysomes by indirect immunoprecipitation. Journal of Biological Chemistry, 249, 3665-71.

Shapiro, S. Z., and Young, J. R., 1981. An immunochemical method for mRNA purification. Ibid. 256, 1495-8.

TAI, H. H., and ChEY, W. Y., 1978. Development of radioimmunoassay for motilin. Analytical Biochemistry, 87, 350-8. 